\title{
Big Sagebrush Control with Tebuthiuron
}

\author{
C.M. BRITTON AND F.A. SNEVA
}

\begin{abstract}
Tebuthiuron ( $20 \%$ a.j. pellets) was applied in 2 years at rates of $0.25,0.5,1.0$, and $2.0 \mathrm{~kg}$ a.i. / ha on sagebrush-grass range. Mortality of big sagebrush (Artemisia tridentata) and herbaceous yield was measured at the end of the second growing season, posttreatment. Mean mortality increased with increasing herbicide rate to $93.9 \%$ at $2 \mathrm{~kg}$ a.i. / ha. Herbaceous yield decreased with increasing herbicide rate to $\approx$ mean of $177.3 \mathrm{~kg} / \mathrm{ha}$ at the $2 \mathrm{~kg} \approx .1 . /$ ha rate contrasted to a mean of $423.9 \mathrm{~kg} / \mathrm{ha}$ for the control.
\end{abstract}

Big sagebrush (Artemisia tridentata) is easily controlled with 2,4-D at rates of 1.0 to $2.0 \mathrm{~kg}$ a.i./ha (Hyder and Sneva 1955). Tebuthiuron ${ }^{1}$ [1-(5-tert-butyl-1,3,4-thiadiazol-2-yl)-1,3-dimethylurea] can effectively control sagebrush at rates of $2 \mathrm{~kg} \mathrm{a.i./} \mathrm{ha}$ (Britton and Sneva 1981). The objectives of this study were to evaluate the effectiveness of tebuthiuron at rates of $2 \mathrm{~kg} \mathrm{a.i./} \mathrm{ha} \mathrm{and}$ less in controlling big sagebrush and subsequent effects on herbaceous yield.

\section{Study Area and Methods}

The study area was on the Squaw Butte Experiment Station Range Unit about $65 \mathrm{~km}$ west of Burns, Ore. This high desert range, elevation $1,370 \mathrm{~m}$, receives mean annual precipitation of about $30 \mathrm{~cm}$. About $60 \%$ of this precipitation occurs during fall and winter, generally as snow, with $25 \%$ as rain during May and June. Soil on the study area is a fine-loamy, mixed frigid Aridic Durixerolls (G. Simonson, pers. comm.).

Shrub-layer vegetation consisted primarily of big sagebrush with scattered green rabbitbrush (Chrysothamnus viscidiflorus) and infrequent horsebrush (Tetradymia canescens) plants. Dominant grasses were bluebunch wheatgrass (Agropyron spicatum), Thurber needlegrass (Stipa thurberiana), bottlebrush squirreltail (Sitanion hystrix), Idaho fescue (Festuca idahoensis), and cheat-

Authors are associate professor, Oregon Agricultural Experiment Station, and research scientist, Agr. Res. Serv. USDA, Burns, Ore. $\mathbf{9 7 7 2 0}$. Britton is currently at the Department of Range and Wildlife Management, Texas Tech University, Lubbock 79409 .

This work involved a cooperative investigation by Oregon Agr. Exp. Sta. and USDA, Agr. Res. Serv., Technical Paper Number 6537, Oregon Agr. Exp. Sta.

Manuscript received November 8, 1982.

'This paper reports the results of research only. Mention of a pesticide in this paper does not constitute a recommendation by the USDA nor does it imply registration under FIFRA. grass (Bromus tectorum). Forbs were present, but constituted less than $10 \%$ of total herbaceous yield.

Plots were established in uniform stands of sagebrush (ca. 7395 plants/ha). Infestations of the sagebrush defoliator (Aroga websterii) from 1962 to 1965 resulted in some residual dead-standing sagebrush plants. Tebuthiuron ( $20 \%$ a.i. pellets) was hand applied with a cyclone seeder at rates of $0.25,0.5,1.0$, and $2.0 \mathrm{~kg} \mathrm{a.i./} \mathrm{ha} \mathrm{to}$ $10 \times 30-\mathrm{m}$ plots. Herbicide pellets were thoroughly mixed with blank pellets to a constant weight of $1,000 \mathrm{~g}$ of material per plot. Herbicide was applied in mid-October 1977 and mid-March 1979. Experimental design was a split-plot in time arrangement of a completely random design with 4 replicates per treatment.

Mortality of sagebrush was determined by counting live and dead plants within a belt established by sweeping a $1-\mathrm{m}$ width around a $20-\mathrm{m}$ line transect. Two belt transects were evaluated per plot. Herbaceous yield was obtained in July by clipping $10,1-\mathrm{m}^{2}$ circular quadrats per plot to a stubble height of $1 \mathrm{~cm}$. Herbage samples were oven dried at $60^{\circ} \mathrm{C}$ for $48 \mathrm{hr}$ and weighed to the nearest gram. Mortality and yield measurements were made at the end of the second growing season post treatment.

\section{Results and Discussion}

High sagebrush mortality rates were obtained with 1 and $2 \mathrm{~kg}$ a.i./ ha rates of tebuthiuron (Table 1). These rates of tebuthiuron produced results similar to the approximate 1 and $2 \mathrm{kga}$ a.i./ ha rates of 2,4-D reported by Hyder and Sneva (1955). There was no treatment difference between years except for the $0.5 \mathrm{~kg} / \mathrm{ha}$ rate, which resulted in a $51.8 \%$ mortality rate for the 1977 fall application compared to $70.9 \%$ for the spring 1979 treatment.

Mean herbaceous yield was significantly decreased with each increasing rate of herbicide (Table 1). This effect at the 1 and 2 $\mathrm{kg} / \mathrm{ha}$ rates was similar to that reported by Britton and Sneva (1981). The inverse incremental herbicide rate-yield relation at rates below $1 \mathrm{~kg} / \mathrm{ha}$ and overall herbaceous sensitivity was less pronounced following spring than fall applied herbicide. That difference does not appear to be associated with total cropyear (Sept.-June) precipitation for the years involved, as totals were near or above normal. Greatest precipitation differences existed in the first growing season post-application when amounts following spring treatments were subnormal, whereas amounts following fall treatments were above normal. However, the lack of acceptable sagebrush mortality from rates less than $1 \mathrm{~kg} /$ ha suggest that the

Table 1. Mean big sagebrush mortality (\%) and herbaceous yield (kg/ha) in 1979 and 1980 for control and 4 rates of tebuthiuron applied in eastern Orezon in fall 1977 and spring 1979.

\begin{tabular}{|c|c|c|c|c|c|}
\hline \multirow[b]{2}{*}{ Response } & \multicolumn{5}{|c|}{ Treatment ( $\mathrm{kg}$ a.i./ ha) } \\
\hline & Control & 0.25 & 0.50 & 1.0 & 2.0 \\
\hline $\begin{array}{l}1979 \text { Mortality }(\%)^{1} \\
1980 \text { Mortality }(\%)\end{array}$ & $\begin{array}{l}19.4^{\star} \\
22.1^{\mathrm{a}}\end{array}$ & $\begin{array}{r}36.0^{\mathrm{b}} \\
26.1^{\mathrm{ab}} \\
\end{array}$ & $\begin{array}{l}51.8^{c} \\
70.9^{d}\end{array}$ & $\begin{array}{l}78.2^{\text {de }} \\
89.3^{\text {ef }}\end{array}$ & $\begin{array}{l}91.6^{f} \\
96.3^{f}\end{array}$ \\
\hline $\begin{array}{l}\text { Mean Mortality }(\%)^{2} \\
1979 \text { Yield (kg/ha) } \\
1980 \text { Yield }(\mathrm{kg} / \mathrm{ha})\end{array}$ & $\begin{array}{r}20.7^{\mathrm{v}} \\
427.8^{d} \\
420.0^{d}\end{array}$ & $\begin{array}{c}31.0^{\mathrm{rw}} \\
255.9^{\mathrm{c}} \\
426.7^{\mathrm{d}}\end{array}$ & $\begin{array}{r}61.3^{w} \\
206.1^{\text {cd }} \\
426.7^{d}\end{array}$ & $\begin{array}{r}83.7^{\mathrm{x}} \\
126.0^{\mathrm{ab}} \\
319.2^{\mathrm{cd}}\end{array}$ & $\begin{array}{r}93.9^{\mathrm{y}} \\
21.8^{\mathrm{a}} \\
212.8^{\mathrm{bc}} \\
\end{array}$ \\
\hline Mean Yield (kg/ha) & $423.9^{2}$ & $341.3^{\mathrm{n}}$ & $316.4^{x}$ & $222.6^{\mathrm{W}}$ & $117.3^{\mathrm{v}}$ \\
\hline
\end{tabular}

IWithin rows and for both years, means for each response separated by letters are different $(P<0.05)$ according to Duncan's multiple range test.

${ }^{2}$ Mean values over years for each response separated by letters are different $(P<0.05)$ according to Duncan's multiple range test. 
question of herbaceous sensitivity to those rates is not paramount in eastern Oregon.

Tebuthiuron is an effective herbicide on big sagebrush. However, at rates necessary to be comparable to $2,4-D$, herbaceous yields were depressed. At the second year post treatment with 2,4-D, yields are generally 3-fold greater on treated areas compared with pretreatment levels (Sneva 1972). Although herbaceous yields are depressed for at least 2 years, the residual tebuthiuron in the soil (Bjerregaard 1977) may effectively control sagebrush seedlings for several years. This would be a positive factor in the longevity of sagebrush control.

\section{Literature Cited}

Bjerregaard, R.S. 1977. Spike for brush control. Fifteenth Ranch Manage. Conf. Proc., Texas Tech. Univ. p. 15-17.

Britton, C.M., and F.A. Sneva. 1981. Effects of tebuthiuron on western juniper. J. Range Manage. 34:30-32.

Hyder, D.N., and F.A. Sneva. 1955. Effect of form and rate of active ingredient, spraying season, solution volume, and type of solvent on mortality of big sagebrush, Artemisia tridentata. Oregon Agr. Exp. Sta. Tech. Bull. No. 35.

Sneva, F.A. 1972. Grazing return following sagebrush control in eastern Oregon. J. Range Manage. 25:174-178. 